Document downloaded from:

http://hdl.handle.net/10251/163180

This paper must be cited as:

Gielen, E.; Riutort-Mayol, G.; Miralles García, JL.; Palencia-Jiménez, J. (2021). Cost assessment of urban sprawl on municipal services using hierarchical regression. Environment and Planning B: Urban Analytics and City Science (Online). 48(2):280-297. https://doi.org/10.1177/2399808319869345

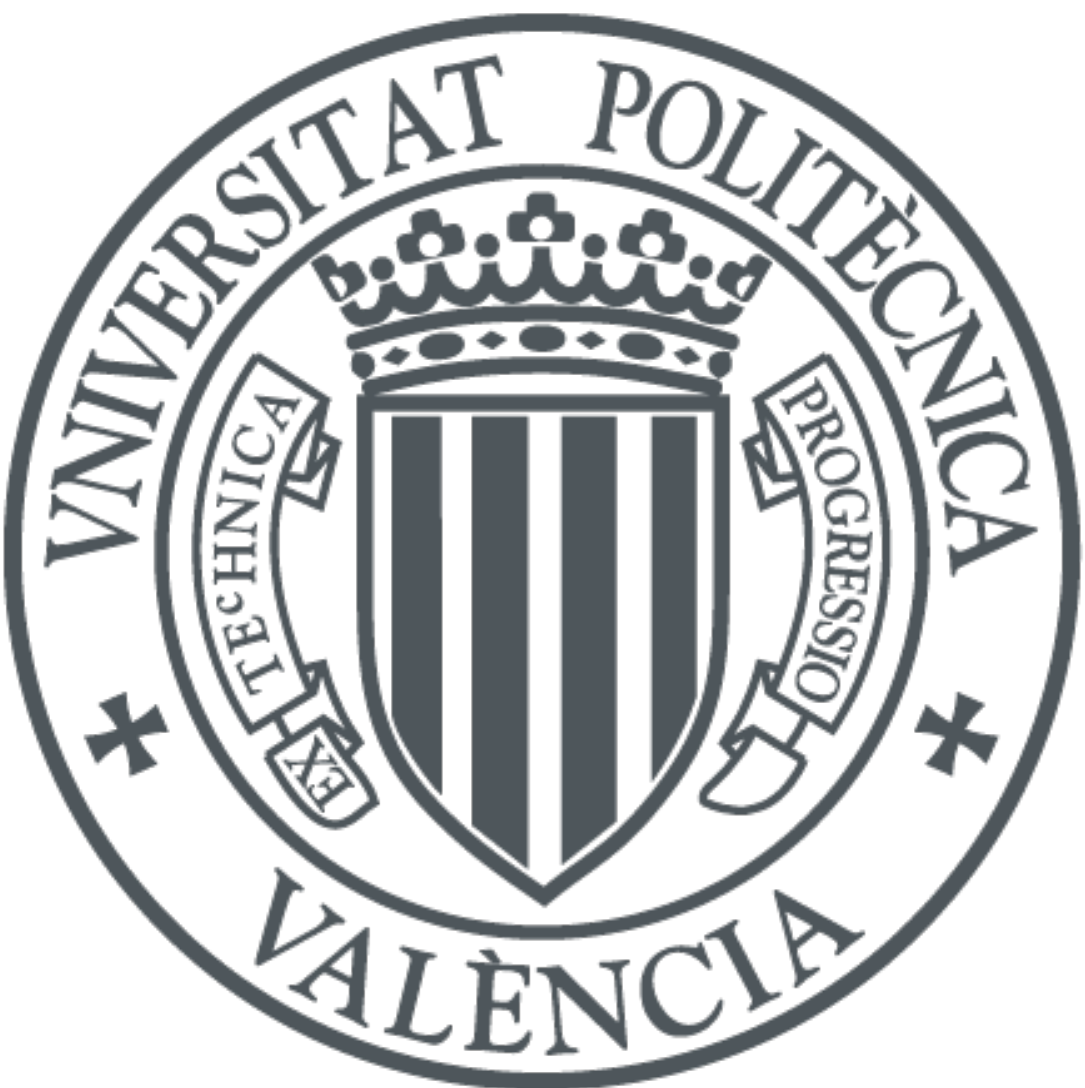

The final publication is available at

https://doi.org/10.1177/2399808319869345

Copyright SAGE Publications

Additional Information 


\title{
Cost assessment of urban sprawl on municipal services using hierarchical regression
}

\begin{abstract}
:
In Europe, especially in the Valencian Community, Spain, the growth of cities in the last few decades has brought with it a major paradigm change, shifting from a compact to a sprawling urban model. Although it is known about its important environmental, social, and economic effects, there is no clear and unequivocal measurement of the impact of urban sprawl on municipal spending. The impact of the sprawling city on public finances and on the cost of local public services is clearly one of the conditioning factors that should be assessed when making urban development decisions.

Based on a measurement of the sprawling city, our aim is to calculate the effect of urban sprawl on the Local Administration's expenditure and particularly on the cost of basic public municipal services. These are obtained through a statistical model with cost functions that can assess the increase in spending prompted by urban sprawl for municipal current expenditure. The proposed model is novel in the field of urban planning, and is based on a Bayesian hierarchical model with the ability to include modeling constraints among the expenditures variables and handle missing values accurately.

With this paper, we show that urban sprawl has a significant and positive effect on the unit cost of local public services, which results in an inefficient urban growth model from the economic point of view. The effect is not transferred homogeneously to the budget. There are spending items that are more sensitive to urban sprawl like expenditure on: security and public transportation and community wellbeing, which primarily covers waste collection, elimination, and treatment; sanitation, and water supply and distribution; road cleaning; and public lighting.
\end{abstract}

Keywords: urban sprawl; cost of public services; municipal budget; hierarchical regression

\section{Introduction}

Urban growth and specifically the urban sprawl model has major environmental, social, and economic effects on a region. The economic effects of urban sprawl can take on a considerable scale at the revenue and expenditure levels. In Spain over the last few decades, many municipalities have adopted expansive urban models to leverage a source of revenue easy to tap into, provoking very high growth and often even more sprawl (EEA, 2006; Burriel, 2008; Gaja, 2008; Miralles, 2014). While the last economic cycle and its associated real estate bubble from 1997 to 2006 lasted (Miralles, 2014), the urban sprawl model was a major short term source of revenue for local Spanish public administrations. However, this expansive growth model was not accompanied by the long term fiscal balance control it was due.

The economic costs may be private when they refer to the costs of goods or services that the home's user has to assume (like transportation, water, or power) or public when it is the administration that has to assume the costs of providing the goods or services to the home.

These public economic costs are mostly covered by town budgets. If a city grows without major changes in the urban morphology, the population increase will produce an expansion in the budget in the same proportion on the expenditure and on the revenue side, thereby maintaining the same budget balance. If urban growth is done varying the urban parameters of the city like density, space, demographics, mix of uses, it is unclear whether the budgetary balance would be maintained. This is precisely the central question of this study which aims to determine the 
direction and magnitude of the changes in municipal public spending produced due to an increase in urban sprawl. There is evidence of the effect of the urban shape on local coffers (Solé-Ollé, 2001, 2005, 2008; Carruthers et al., 2003; Hortas-Rico, 2010, 2014; Benito et al., 2010), attributing higher costs in the provision of basic public services.

The description of urban sprawl usually focuses on measuring the degree of compactness-sprawl of the entire municipal urban area. There have been several approaches to measuring this index: some use population or housing density (Carruthers et al., 2003; Hortas-Rico, 2010; Benito et al., 2010), the number of hubs and the percentage of the population spread out (Solé-Ollé, 2001; Solé-Ollé et al., 2008; Hortas-Rico et al., 2013), and other indexes of fragmentation of urban areas (Sapena et al., 2015). However, in all of them, the characterization of the urban landscape is only partial.

This article aims to be a study in quantification and analysis of the effect of urban sprawl on spending on basic municipal public services for all of the municipalities in the Autonomous Community of Valencia in Spain. As an index of urban sprawl we make use of the index calculated in Gielen et. al. (2018), which is an urban sprawl index calculated as the latent factor related to a group of 12 characteristics related to the land use in each town, making use of the Bayesian factorial analysis methodology for its calculation. This urban sprawl index covers more aspects and characteristics of the sprawling city than any previous paper.

The relationship between the urban sprawl index and each of the budgetary variables is assessed using the Bayesian regression model adjustment and formula for each of the variables. The hierarchical relationships that exist between the different expenditure variables are modeled so that the different expenditure variables could share information between them and in that way obtain more accurate and reliable estimates. The use of the Bayesian approach to formulate and estimate the regression models has allowed us to take full advantage of the available data set because it takes into consideration the missing data that exist in the data set. The Bayesian approach allows for statistical inference of the missing data simultaneously with the model's inference, a real and efficient way to use the entire database when there are missing data in it. Furthermore, the values equal to zero in the expenditure variables do not usually correspond to a zero cost for a certain variable, but indicate that certain service is not provided by a municipality. The proposed model has the ability to jointly model these values equal to zero and the real expenditure values, and share information among them. The proposed model with all these modeling features is novel in the field of urban planning.

As a result, we were able to determine what municipal expenditure variables were dependent on urban sprawl and obtain a series of cost functions to assess the increase in current municipal spending according to urban sprawl.

\section{Background}

2.1 Relationship between urban sprawl and municipal expenditure

Although some authors grant a positive fiscal balance to urban development with less density (Speir et al., 2002), most suggest a clearly loss-making economic balance. According to Muñiz (2006), the sprawl model is clearly inefficient from the economic perspective: the public and private cost of a house in an apartment building is lower than for a single-family detached or row house. 
The costs far outstretch benefits and although some benefits may exist in isolated cases, this balance appears to be loss-making in general terms (Ewing, 1994, quoted by Pichler, 2007; Miralles et al.; 2013). In addition, Brueckner (2001) demonstrates that the promotion of new sprawling residential neighborhoods, far from the city, is artificially less expensive than it is in actuality. According to this author, paying additional taxes does not usually cover the marginal costs of providing new infrastructure (highways, sewage systems, electrical and gas grid, schools, parks, and recreational areas), which creates a net individual benefit for the new owner over the net social benefit.

There is an abundance of international literature which attributes the economic cost overrun of urban sprawl much of which has to do with higher expenses in the provision of public services assumed by municipalities (RERC, 1974; Burchell et al., 2003; Speir, 2002; Carruthers et al., 2003). The Real Estate Research Corporation of the United States in a study called 'The Costs of Sprawl' (RERC, 1974) estimated that, in the service exploitation stage, once the city has been built and inhabited, an urban development with less density is twice as expensive as others that are denser (Carruthers et al.; 2003, quoting RERC, 1974). In Switzerland, the Office Fédéral du Développement Territorial (2000) indicates three times the costs for public sanitation and water distribution, trash collection, roads, and electricity. Burchell et al. (2003) estimate that the sprawling city generates $10 \%$ more deficit in public service costs as well as $10 \%$ more highways and $8 \%$ in housing costs. Carruthers et al. (2003) establishes that the type of urban development has an effect on the expenditure associated with transportation infrastructure, trash collection, road cleaning, police, firefighters, public parks, and libraries. The study shows that higher density, which leverages economies of scale, reduces the unit cost of providing public services and that the spatial extension of urban development increases those same costs. The properties of density, distance, and fragmentation that define the sprawl of urban space have a direct effect of higher costs for the services of water sanitation and distribution (Speir et al., 2002). There are also authors like Ladd (1994), quoted by Carruthers et al. (2003) who argue the opposite: higher density produces higher costs for public services and even demonstrate the existence of a nonlinear relationship in which, at first, at very low densities, the costs decrease as density increases, and then, as it approaches higher densities, rise again. In Europe, Guengant et al. (1995), quoted by Garrido et al. (2013), concluded that density had no economic effect on the cost of public services.

In Spain, several authors have studied the relationship between urban sprawl and the cost of public services. According to Muñiz (2006), maintaining certain levels of public services in disperse areas "implies higher costs than for a compact and dense area." Garbiñe (2007) estimates that the maintenance costs for public services per house in a development with row houses (water distribution, sanitation, lighting, cleaning, and development) can cost up to seven times a development in an urban center. The work done by Solé-Ollé (2001), Solé-Ollé and Bosch (2005) underscore this idea: urban sprawl has a positive and significant impact on the cost of municipal public services. These same results can be found in more recent studies carried out from 2008 to 2014 by Solé-Ollé and Hortas-Rico: a 1\% increase in the area built-up per capita increases the current expenditure by $0.11 \%$ (Solé-Ollé et al., 2008); urban sprawl is responsible for a $2.3 \%$ growth in the cost of basic public services which is $7 \%$ in the infrastructure chapter, $2.3 \%$ in goods and services, $2 \%$ in housing and police, $2.7 \%$ in administrative services, and $3.7 \%$ in culture. It also shows that in $4 \%$ of the municipalities analyzed, this increase was over $10 \%$ (Hortas-Rico et al., 2010). 
2.2 Variables and methods used in the cost estimate

The economic impact of urban sprawl has been studied through input-output studies and econometric studies. The first are empirical studies that aim to draw up a prototype that analyzes the influence of urban space's development characteristics on the economic flows involved (Real Estate Research Corporation, 1974; Office Féderal du Developpement Territorial, 2000; Garbiñe, 2007; Moral, 2010; Paulsen, 2013). The second, more recent, use econometric techniques that due to progress in computer processing, the availability of the amount of economic data, and more knowledge about the variables being used are better equipped to paint a more realistic picture. In Spain, the studies by Solé-Ollé $(2001,2005,2008)$, Hortas-Rico (2010, 2013) and Benito et al. (2010) were carried out with these kinds of methodologies, attempting to establish the relationship between urban sprawl and municipal expenditure on basic public services. In most of these studies, least squares was used to analyze the determining factors of local spending which was combined in some cases with segmented linear regression techniques (Sole-Ollé, 2005; Benito, 2010; Hortas-Rico, 2010; Hortas-Rico 2013), assuming a non-linear relationship between expenditure and independent variables like population.

Location factors or of urban configuration considered by other authors are: developed area per capita (Solé-Ollé, 2001; Sole-Ollé, 2008, Hortas Rico, 2008; Hortas-Rico, 2014), percentage of single-family houses (Sole-Ollé, 2008), number of population centers (Sole-Ollé, 2008), percentage of dispersed population (Sole-Ollé, 2008; Hortas-Rico, 2014), density, land value, and total developed area (Carruthers et al., 2003). There are also other social or demographic variables like population structure or education (Solé-Ollé, 2001; Cabasés et al, 2012; Benito, 2010; Hortas-Rico, 2014); economic variables, like income, the weight of tourism or industry (Solé-Ollé, 2001; Carruthers et al., 2003, Hortas-Rico, 2014; Benito et al., 2010); political and institutional variables in Solé-Ollé (2001) and Cabasés et al. (2012); variables related to the financial situation of the administration (Solé-Ollé, 2001; Benito et al., 2010; Cabasés et al., 2012), and territorial variables like the capacity of the centers or grouping of municipalities (Hortas-Rico, 2014). In Spain, the study by Solé-Ollé (2001) covers the most variables.

\section{Methodology}

3.1 Conceptual model.

Despite the recognition of the importance of the relationship between public finance and urban form (RERC, 1974; Solé-Ollé, 2001; Speir, 2002; Burchell et al., 2003; Carruthers et al., 2003; Solé-Ollé and Bosch, 2005), this is, in a large extend, an undeveloped assumption and urban planners do not have yet the assessing tools to evaluate the effect of the urban model they project.

In order to model the expenditures in the public finances of a municipality, several factors have to be taken into consideration. First, the expenditure in a certain budgetary variable is dependent on the amount of services that it includes. Which amount of services included depends on the population size of the municipality, as established in the Spanish Local Regime Basic Law of 1985. In addition, this expenditure also depends on the demand for services, such as the greater the demand for houses or people, the higher the cost. Furthermore, the quality of the services provided also affects their costs. And finally, the cost of providing public services depends on the established urban model, since it governs the characteristics and the dynamics of the supply and capture of the services (Solé-Ollé, 2001; Speir, 2002; Burchell et al., 2003; Carruthers et al., 2003; Solé-Ollé and Bosch, 2005). 
From this evidence, a 'cost function' for the municipal expenditures can be expressed in a conceptual form that includes the effects of the different factors. This 'cost function' can be represented by some function $f$,

$$
E=f(s, n, q, u)
$$

where $E$ represents the expenditure in a budgetary variable of a municipality, $s$ the amount of services provided, $n$ the demand for the services, $q$ the quality of the services and $u$ the established urban model in the municipality.

Assuming that the factors $s$ and $q$ might be constant over time for a municipality. Since both the amount of services, which are set for the Spanish Local Regime Basic Law according to the population size and the quality of the services are not expected to change in the short term. Thus, the remaining factors in the cost function are the demand for the services $n$ and the urban model $u$. If the municipality expenditures are expressed per unit of service demand, so that $e=E / n$, we obtain a 'cost function' for a municipality only as a function of the urban model:

$$
e=g(u)
$$

$g(u)$ represents a certain 'cost function' that depends on the urban model $u$.

This conceptual model can be a framework on which the modeling of a 'cost function' for a municipality should be based on. The determination of a 'cost function' allows us to estimate the effects a new urban pattern might cause on the expenditures of a municipality. The 'cost function' can give the planners a more active role with a decision-making tool that incorporates spatial characteristics of the urban model.

Further on, the present work is focused on the determination of the 'cost function' $g$ as a function mainly of the urban model for all the municipalities of the Valencian Community in Spain. The urban model is characterized by an index, called sprawl index (Gielen et al. (2018)).

\subsection{Area of study and sample units}

The study is of 542 municipalities in the Autonomous Community of Valencia, Spain, on the Mediterranean coast, corresponding to NUTS 2 level of the Nomenclature of Territorial Units for Statistics of the EU (Figure 1). The territory has an area of $23,255 \mathrm{~km}^{2}$ with more than 5 million in population, and is divided into three provinces: Castellon, Valencia and Alicante.

The Autonomous Community of Valencia is known for its particular Valencian urban development model (Fortbou, 2005; Burriel, 2008; Gaja, 2008; Miralles, 2014), which due to its geographic location and its productive model based on tourism triggered a real estate boom and an expansive urban model (EEA, 2006). 
The municipality is the minimum unit of observation and analysis in this study. Until now, there have only been similar studies of samples of few Spanish municipalities (Solé-Ollé et al., 2008; Hortas-Rico, 2010; Benito et al., 2010; Hortas-Rico et al., 2013) and the province of Barcelona (Solé-Olle, 2001). The sample chosen has several advantages when compared to these studies: one, the Community of Valencia has its own regulatory framework in urban development; two, it is a large and diverse enough sample to run the statistical analysis in its territorial characteristics which vary considerably if the town is inland or on the coast; three, there are full and standard data on land use and public finance; last, the previous paper by Gielen et al. (2018) offers a synthetic index of sprawl already calculated for all of the municipalities in the study's scope.

\subsection{Budget expenditure variables}

The expenditure variables were obtained from budget settlement data for local institutions published by the Virtual Offices for Financial Coordination with the Local Institutions of the Secretariat-General of Autonomous and Local Coordination of the Ministry of Finance and Public Administrations. The concept of expenditure used in this study is current expenditure. Capital and financial transactions are not included since they are the result of more volatile and complex decisions, with longer timeframes than current expenditure (Solé-Ollé, 2001). Expenditure variables were defined in euros per house and at the municipal level.

In comparison with other studies carried out in Spain, a more complete budget data set is analyzed: several budgetary fiscal years are used, specifically from 2010 to 2013, and the authors work with a new organization of the data that corresponds to the structure of the budgets of the local institutions in effect since 2008. In that way, more detailed budgetary data is included, up to a third hierarchical level (expenditure program groups). The effect on the different basic public municipal services can be differentiated and individualized results obtained for sanitation, supply and distribution of water, collection, elimination, and treatment of waste, road cleaning, and public lighting.

Table 1 shows the different expenditure variables. They respond to a hierarchical structure with four levels in line with the classification of municipal budgets in Spain. Not all of the expenditure 
of this classification was considered; only expenditure variables that might, a priori, be affected (Solé-Ollé, 2001; Solé-Ollé and Bosch, 2005; Muñiz, 2006; Garbiñe, 2007).

\begin{tabular}{|c|c|c|}
\hline Variable & Level & Type of expenditure \\
\hline Etot & 1 & Total current \\
\hline E1 & 2 & Basic public services \\
\hline E13 & 3 & Security and public transportation \\
\hline $\boldsymbol{E} 132$ & 4 & Security and public order \\
\hline $\boldsymbol{E 1 5}$ & 3 & Housing and development \\
\hline $\boldsymbol{E 1 5 1}$ & 4 & Development \\
\hline $\boldsymbol{E 1 5 5}$ & 4 & Public roads \\
\hline $\boldsymbol{E 1 6}$ & 3 & Community wellbeing \\
\hline $\boldsymbol{E 1 6 1}$ & 4 & Sanitation, and water distribution and supply \\
\hline $\boldsymbol{E 1 6 2}$ & 4 & Waste collection, elimination, and treatment \\
\hline $\boldsymbol{E 1 6 3}$ & 4 & Road cleaning \\
\hline $\boldsymbol{E} 165$ & 4 & Public lighting \\
\hline E17 & 3 & Environment \\
\hline $\boldsymbol{E 1 7 1}$ & 4 & Parks and gardens \\
\hline
\end{tabular}

Table 1: Dependent variables

\subsection{Explanatory variables}

The explanatory variables in the regression model are those that supposedly have an explanatory effect on the response variable or budgetary expenditure variable (Table 2). Naturally, the most important explanatory variable whose effect we are interested in is the urban sprawl index. This is a one-dimensional variable that acts as a synthesis of the multidimensional phenomenon of urban sprawl and was proposed in the research done by Gielen et al. (2018). This sprawl index was based on computing the underlying common factor to a wide set of input variables concerning density, land occupation, form and structure of the urban patches, by means of using Bayesian factor analysis. It is a continuous variable, of an approximately normal distribution, dimensionless and with an approximate range of -2.5 to +2.5 , indicating less or more sprawl according to the value of the index.

There are other explanatory factors that can have an effect on municipal expenditure. They are taken as secondary variables because, in principle, they are not the direct subject of this study, but they have been included since we suspect they might affect the cause-effect relationship between sprawl and expenditure. These variables are related to municipal size (set by the municipal authorities), the specialization in land use, and the existence of budgetary conditioning factors like income from fiscal pressure and other expenditure for payment of certain services through transfers to other administrations.

\begin{tabular}{|c|c|c|}
\hline $\begin{array}{l}\text { Explanatory } \\
\text { variables }\end{array}$ & Definition & Data calculation and source \\
\hline Sprawl & Sprawl index & Gielen et al. (2018) \\
\hline \multirow[t]{4}{*}{ Tрор } & $\begin{array}{l}\text { Population size. Categorical variable defined in } \\
\text { three classes: }\end{array}$ & Population data (2011 census) \\
\hline & $-\quad<1,000$ inhabitants (tpop1) & \\
\hline & - $1,000-5,000$ inhabitants (tpop2) & \\
\hline & - > 5,000 inhabitants (tpop3) & \\
\hline IndTer & $\begin{array}{l}\text { Proportion of industrial/tertiary area to } \\
\text { residential population area }\end{array}$ & SIOSE 2011 data \\
\hline SecHom & Importance of second home in overall housing & idem \\
\hline$S N E$ & $\begin{array}{l}\text { Weight of undeveloped area in residential and } \\
\text { industrial developments }\end{array}$ & idem \\
\hline ExpTransf & $\begin{array}{l}\text { Expenditure in transfers to other public } \\
\text { administrations }\end{array}$ & $\begin{array}{l}\text { Data on budgetary settlements of } \\
\text { local institutions of the Secretariat- }\end{array}$ \\
\hline
\end{tabular}




\subsection{Regression model}

A statistical regression model is proposed to estimate the effects of urban sprawl on municipal expenditure and investigate the existence of a certain correlation between current expenditure on public goods and services and the type of urban model.

The model estimates the relative cost, equal to the marginal increase in expenditure in a certain budgetary variable when the index of urban sprawl increases by one unit:

$r=\frac{G^{S+1}}{G^{S}}$

where $r$ is the increase of relative cost, $E^{S+1}$ is the current expenditure on a certain expenditure variable of a municipality with a sprawl index $S+1$ and $E^{S}$ is the municipality's current expenditure with an $S$ sprawl index.

A Bernouilli-Gamma regression model is developed (Paradinas et al., 2015), with a Bayesian focus (Ntzoufras, 2009). The Bernouilli-Gamma model is characterized by modeling the expenditure variables through mixing two distributions: a Bernouilli distribution that models whether a value is zero or not and a Gamma distribution that models the values not equal to zero.

The values equal to zero in the database are not usually zero cost for a certain item; instead they usually indicate a municipality's lack of power to provide a certain service, so the results of the Bernouilli model will mainly reflect the effect of those budgetary powers and not the real zero expenditure on providing a certain service.

The results of this investigation will be mainly those that come from the Gamma model, i.e. the modeling of values not equal to zero. The formulation of this mixed model allows for a compact and complete modeling of the observed expenditure data and to analyze the distribution of the 
values not equal to zero, real expenditure values, and values equal to zero together and detect and estimate the possible driving factors in both cases.

The Bernouilli model models the observations 0 or 1 for each municipality where 1 indicates that a municipality has an expenditure not equal to zero. The model depends on the probability $p(i)$ (probability of being 0 or 1 ):

$f(p(i))=\operatorname{Ber}(u(i) \mid p(i))$,

where $u(i)$ is the 0 or 1 valued observed for a municipality $\mathrm{i}\left(i=1, \ldots \ldots \ldots, n=n^{\mathrm{o}}\right.$ de municipios $)$ , $p(i)$ is the probability that value 1 for municipality $\mathrm{i}$, where $(1-p(i))$ would be the probability of the value 0 .

Expenditure values $y$ not equal to zero are modeled using the Gamma model since the expenditure values not equal to zero are strictly positive values and have asymmetrical distribution:

$$
\begin{gathered}
f(a(i), b(i))=G_{A}(y(i) \mid a(i), b), \\
a(i)=\mu(i) \cdot b,
\end{gathered}
$$

where $a(i)$ and $b$ are respectively the form and ratio parameters of the Gamma distribution, and $\mu(i)$ is the measurement of the Gamma distribution. Note that the $b$ ratio parameter has been considered to be equal for all the municipalities $\mathrm{i}$.

To combine the Bernouilli and Gamma models in order to form a mixed model, the $\mu(i)$ measurement of the Gamma model must be conditioned by the $u(i)$ value of the Bernouilli model by the expression in (1), so that if the observed value $u(i)$ is equal to 1 , the functional regression's entire expression is shown in the parameter $\mu^{\prime}(i)$. If $u(i)$ is equal to 0 the measurement $\mu(i)$ of the Gamma distribution is equal to 0 :

$$
\mu(i)=u(i) \cdot \mu^{\prime}(i)
$$

With that, the overall likelihood function of the Bernouilli-Gamma model takes the form:

$$
f(p(i), a(i), b)=\operatorname{Ber}(u(i) \mid p(i)) \cdot G_{A}(y(i) \mid a(i), b)
$$

The linear regression (3) is defined on the logarithm of the average $\mu^{\prime}(i)$, and includes the explanatory quantitative factors Sprawl, IndTer, ExpTrans, Pressure, SecHom, SNE and the categorical covariable of the type of population $\operatorname{tpop}(i)$. Coefficients $\beta_{k}$ measure the effect of the quantitative covariables on the logarithm of the average $\log \left(\mu^{\prime}(i)\right)$. Coefficient $\beta_{0}$ is the global average of the model and factor $P(\operatorname{tpop}(i))$ measures the effect on $\log \left(\mu^{\prime}(i)\right)$ of belonging to a certain $\operatorname{tpop}(i)$ population group. Coefficient $\beta_{1}$ is differentiated by population groups $\operatorname{tpop}(i)$. The possible correlation between the population type variable tpop $(i)$ and the Sprawl index has been minimized by including their interaction, allowing the effect of the $\beta_{1}$ on the sprawl to be different in each population group tpop $(i)$.

$$
\begin{aligned}
& \log \left(\mu^{\prime}(i)\right)=\beta_{0}+P(\operatorname{tpob}(i))+\beta_{1}(\operatorname{tpop}(i) \cdot \operatorname{Sprawl}(i))+\beta_{2} \cdot \operatorname{IndTer}(i)+\beta_{3} . \\
& \operatorname{GastTrans}(i)+\beta_{4} \cdot \operatorname{Presion}(i)+\beta_{5} \cdot \operatorname{VivSec}(i)+\beta_{6} \cdot \operatorname{SNE}(i)
\end{aligned}
$$

Generalizing the previous model for different expenditure variables $\mathrm{j}$ and observed in different periods $t$, so that the expenditure data for different years are included, you have:

$u(i, j, t) \sim \operatorname{Bernoulli}(p(i, j, t))$ 
In the previous expressions (4) and (5), $x$ represents a certain value of any quantitative covariable $\mathrm{Cov}_{k}$, and $a$ and $b$ represent two categories of the population type variable tpop(i).

The hierarchical relationships between the budgetary variables is as (6). Taking into account these relationships in the modeling improves the estimations of the parameters and the inference of the missing data.

$$
G 1=G 13+G 15+G 16+G 17
$$

Bayesian inference is done over the posterior marginal joint distribution of parameters given the data, which is proportional to the likelihood and priors,

$f(b, \beta, P, p \mid y)=f(y \mid b, \beta, P, p) \cdot f(b, \beta, P, p)$

where, $f(y \mid b, \beta, P, p)$ is the likelihood of the model $(2)$ and $f(b, \beta, P, p)$ the joint prior of the hyperparameters.

We set weak prior distributions $f(b)=G_{A}(2,50), f(\beta)=N(0,10), f(P(t p o p=2))=N(0,10)$, $f(P($ tpop $=3))=N(0,10), f(P($ tpop $=0))=0, f(p)=U(0,1)$ for the hyperparameters $b, \beta$, $P$ and $p$, respectively, based on prior knowledge about the magnitude of the parameters. So, the marginal posterior joint distribution that results is:

$f(b, \beta, P, p \mid y)=G_{A}(b, \beta, P) \cdot \operatorname{Ber}(u \mid p) \cdot G_{A}(2,50) \cdot N(0,10) \cdot N(0,10) \cdot U(0,1)$

To estimate the parameters of the posterior distribution for this model, simulation methods can be used. Simulating methods based on Markov Chain Monte Carlo (MCMC) (Brooks et al., 2011) are general sampling methods based on drawing values of the parameters from approximate distributions and then correcting those draws to better approximate the target posterior distribution. We used MCMC using Gibbs sampling (Geman and Geman, 1984) and the WinBUGS software (Lunn et al., 2000) to estimate the model (Ntzoufras, 2009). Three simulation chains were launched with different initial values. 


\section{Results}

The estimate of the effects of the explanatory factors was undertaken based on parameters $\beta$ of the statistical model mentioned in the section above and are expressed in terms of relative expenditure increase. Our interest focuses on the results of the Gamma model that gathers and models the distribution of the real expenditure values.

The distribution of later probability estimated for each of the parameters $\beta$ allows inferring the following results: the credible interval, the average, and the typical deviation. The credible intervals and the typical deviation are a measurement of the accuracy of the parameters' estimate. Based on the later probability distribution, a measurement of the significance of the parameter can be estimated, where significance is the probability that the parameter is not void or equal to zero. The meaning and interpretation of parameter $\beta$ is done in terms of relative risk, where the exponential of $\beta_{k}(j)$ represents the increase of relative expenditure in variable $j$ due to the increase of one unit in the measurement of the covariable $k$

$$
\exp \left(\beta_{k}(j)\right)=\frac{\mu(i, j) \mid \operatorname{Cov}_{k}=x}{\mu(i, j) \mid \operatorname{Cov}_{k}=x+1},
$$

where $x$ represents a certain value of any quantitative covariable $\operatorname{Cov}_{k}$.

If the covariable $k$ is the sprawl index then we can calculate the effect on the cost of the expenditure variable $j$; the increase of relative expenditure in expenditure $j$, like the logarithm of $\beta(j)$.

The precision of the estimate of the effect is determined by the width of the credible interval or the standard deviation of the parameter's variability.

The lower (low) and upper (up) limits of credible interval at 95\%, the average (av) and the typical deviation (dev) are the values presented in tables 4,5 , and 6 which contain the results of the estimate of parameter $\beta_{1}$, a parameter associated with the effect of the sprawl index explanatory variable. Parameter $\beta_{1}$ is differentiated by type of population (tpop).

\begin{tabular}{|c|c|c|c|c|c|c|c|c|}
\hline & \multicolumn{4}{|c|}{ Etot } & \multicolumn{4}{|c|}{ E1 } \\
\hline Parameter & Av. & dev. & [low & up] & Av. & dev. & [low & up] \\
\hline$\beta_{1}(t p o p=1)$ & 0.20 & 0.02 & 0.16 & 0.23 & 0.32 & 0.03 & 0.26 & 0.37 \\
\hline$\beta_{1}(t p o p=2)$ & 0.18 & 0.02 & 0.15 & 0.22 & 0.23 & 0.03 & 0.18 & 0.28 \\
\hline$\beta_{1}(t p o p=3)$ & 0.19 & 0.01 & 0.16 & 0.22 & 0.25 & 0.02 & 0.20 & 0.29 \\
\hline
\end{tabular}

Table 4: Results of parameter $\beta_{1}$ for Etot and E1.

\begin{tabular}{|c|c|c|c|c|c|c|c|c|c|c|c|c|c|c|c|c|}
\hline \multirow[b]{2}{*}{ Variable } & \multicolumn{4}{|c|}{ E13 } & \multicolumn{4}{|c|}{$E 15$} & \multicolumn{4}{|c|}{ E16 } & \multicolumn{4}{|c|}{ E17 } \\
\hline & Av. & dev. & [low & up] & Av. & dev. & [low & up] & Av. & dev. & [low & up] & Av. & dev. & [low & up] \\
\hline$\beta_{1}(t p o p=1)$ & 0.32 & 0.06 & 0.21 & 0.42 & 0.28 & 0.04 & 0.21 & 0.36 & 0.25 & 0.03 & 0.19 & 0.31 & 0.19 & 0.06 & 0.08 & 0.31 \\
\hline$\beta_{1}(t p o p=2)$ & 0.18 & 0.04 & 0.10 & 0.27 & 0.08 & 0.04 & -0.02 & 0.16 & 0.23 & 0.03 & 0.17 & 0.29 & 0.14 & 0.05 & 0.05 & 0.25 \\
\hline$\beta_{1}(t p o p=3)$ & 0.19 & 0.03 & 0.14 & 0.25 & 0.13 & 0.04 & 0.07 & 0.20 & 0.32 & 0.03 & 0.26 & 0.37 & 0.18 & 0.05 & 0.10 & 0.27 \\
\hline
\end{tabular}


Table 5: Results of parameter $\beta_{1}$ for E13, E15, E16 and E17

\begin{tabular}{|c|c|c|c|c|c|c|c|c|c|c|c|c|c|c|c|c|}
\hline Variable & \multicolumn{4}{|c|}{ E132 } & \multicolumn{4}{|c|}{ E151 } & \multicolumn{4}{|c|}{ E155 } & \multicolumn{4}{|c|}{ E171 } \\
\hline & Av. & dev. & [low & up] & Av. & dev. & [low & up] & Av. & dev. & [low & up] & Av. & dev. & [low & up] \\
\hline$\beta_{1}(t p o p=1)$ & 0.37 & 0.17 & 0.06 & 0.72 & 0.28 & 0.11 & 0.04 & 0.49 & -0.14 & 0.16 & -0.43 & 0.17 & 0.25 & 0.18 & -0.10 & 0.64 \\
\hline$\beta_{1}(t p o p=2)$ & 0.21 & 0.04 & 0.13 & 0.29 & 0.07 & 0.08 & -0.09 & 0.22 & 0.23 & 0.08 & 0.07 & 0.37 & 0.21 & 0.09 & 0.03 & 0.39 \\
\hline \multirow[t]{2}{*}{$\beta_{1}(t p o p=3)$} & 0.11 & 0.02 & 0.06 & 0.15 & 0.14 & 0.05 & 0.04 & 0.24 & 0.14 & 0.06 & 0.05 & 0.26 & 0.18 & 0.05 & 0.07 & 0.27 \\
\hline & \multicolumn{4}{|c|}{ E161 } & \multicolumn{4}{|c|}{ E162 } & \multicolumn{4}{|c|}{ E163 } & \multicolumn{4}{|c|}{ E165 } \\
\hline Variable & Av. & dev. & [low & up] & Av. & dev. & [low & up] & Av. & dev. & [low & up] & Av. & dev. & [low & up] \\
\hline$\beta_{1}(t p o p=1)$ & 0.37 & 0.16 & 0.08 & 0.73 & -0.04 & 0.06 & -0.15 & 0.07 & 0.80 & 0.28 & 0.13 & 1.18 & 0.10 & 0.07 & -0.06 & 0.22 \\
\hline$\beta_{1}(t p o p=2)$ & 0.11 & 0.09 & -0.07 & 0.28 & 0.19 & 0.05 & 0.09 & 0.27 & 0.01 & 0.12 & -0.23 & 0.26 & 0.05 & 0.06 & -0.08 & 0.15 \\
\hline$\beta_{1}(t p o p=3)$ & 0.21 & 0.06 & 0.10 & 0.33 & 0.39 & 0.03 & 0.33 & 0.46 & 0.15 & 0.07 & 0.01 & 0.28 & 0.15 & 0.04 & 0.08 & 0.24 \\
\hline
\end{tabular}

Table 6: Results of parameter $\beta_{1}$ for E132, E151, E155, E171, E161, E162, E163 and E165

The results are consistent with expectations: one, the data show significant effects in many of the expenditure variables, with magnitudes and directions similar to those expected; two, the credible intervals are relatively consistent, showing little variability in the parameters, confirming an accurate estimate in the magnitude of the effects, particularly in the expenditure variables on which urban sprawl was expected to have an effect. This demonstrates that the model is able to predict the effects in a fairly precise way, converging towards a solution with limited variability.

\section{Discussion}

The results of the model show a positive effect of urban sprawl on the municipal budget at the total current expenditure level and on most of the expenditure variables analyzed. This demonstrates a correlation between the municipal expenditure and the factors of the town's location or the urban fabric.

The results are more precise in estimating the effect for Etot and $E 1$. The credible variables grow wider as the expenditure variables are more disaggregated because fewer data are available. However, although they are less accurate, the effects are more verified between the different variables. This can be explained by the specialization of expenditure or by an excessive generalization of the expenditure variable $E 1$ and Etot. Finally, the model estimates the effect on municipalities with more than 5,000 inhabitants more accurately because the data are more complete in large municipalities.

The effect of the sprawl index on the total current expenditure (Etot) is significant and positive, slightly higher in municipalities with more than 5,000 inhabitants and less than 1,000 inhabitants. The accuracy of the estimate is high. According to the results obtained, for each increase of one unit in the sprawl (the value for the sprawl index proposed by Gielen et al. (2018) has an approximate range of -2.5 to +2.5 ), the total current expenditure increases $19 \%$ in municipalities with 1,000 to 5,000 inhabitants, and $21 \%$ in the case of the other municipalities. These results coincide with numerous authors who conclude that the location guidelines are 
especially relevant in total current expenditure (Solé-Ollé, 2001; Carruthers et al., 2003; SoléOllé et al., 2008; Benito, 2010; Hortas-Rico, 2010; Hortas-Rico, 2014).

The results for the expenditure variable in Basic Public Services (E1) demonstrate an even greater effect, being significantly very positive. The credible interval indicates high pressure on the estimate of the effect's magnitude. The effect varies according to the type of town and is greater in municipalities with fewer than 1,000 inhabitants. In this case, the increase of one unit of the sprawl index increases the expenditure on basic public services by $38 \%$. In municipalities with 1,000 to 5,000 inhabitants, that percentage is $26 \%$ and in municipalities with more than 5,000 it is $28 \%$. This result is relatively new in the case of Spain since there is no recent research on data with the current budgetary structure. Even so, it coincide with bibliographic references that note a greater cost for the sprawled city in community wellbeing policies (Solé-Ollé, 2001; Carruthers et al., 2003; Solé-Ollé et al., 2008; Hortas-Rico, 2014), that mostly coincide with the variable $E 1$.

Differentiating between Basic Public Services, the model demonstrates a significantly positive effect on expenditure in Security and public transportation (E13). The increased expenditure from the increase of one unit in the sprawl index is $19 \%$ in municipalities with 1,000 to 5,000 inhabitants and $21 \%$ in municipalities with more than 5,000 inhabitants. The effect is even greater in municipalities with fewer than 1,000 inhabitants but less accurate. The expenditure subvariable in Security and Public Order (E132) presents very similar results in the case of municipalities with more than 1,000 inhabitants. These conclusions coincide to a large extent with other authors: Solé-Ollé (2001 and 2008) demonstrate a similar effect of density; Carruthers et al. (2003) obtains a positive effect of sprawl on spending on the police; Ewing (2008) also establishes a positive effect, attributing it to the distance and fragmentation more than density.

In the expenditure variable in Housing and Urban Development (E15), the result obtained shows a positive effect, greater in municipalities with fewer than 1,000 inhabitants and more than 5,000 inhabitants. The increase in the sprawl index of a unit means a $37 \%$ increase in expenditure in municipalities with fewer than 1,000 inhabitants and $14 \%$ in municipalities with more than 5,000 inhabitants. In municipalities with 1,000 to 5,000 inhabitants, that increase is lower and cannot be predicted with enough reliability. The results partially coincide with Carruthers et al. (2003). In terms of the expenditure subvariables in Urban Development (E151) and Public roads (E155) (Figure 5) the previous statements are reaffirmed although with less accuracy especially in municipalities with fewer than 1,000 inhabitants.

In the expenditure variable in Community Wellbeing (E16), urban sprawl has a very positive and significant effect, slightly greater than in municipalities with more than 5,000 inhabitants. The increase of expenditure that corresponds to an increase of one unit in the sprawl index is $29 \%$ in municipalities with fewer than 1,000 inhabitants, $26 \%$ in municipalities with 1,000 to 5,000 inhabitants, and $38 \%$ in municipalities with more than 5,000 inhabitants. These results are similar to the conclusions reached by Solé-Ollé (2001) and Solé-Ollé et al. (2008).

Within expenditure subvariables of $E 16$ Community Wellbeing is examined:

- In spending on Sanitation, and water supply and distribution (E161), the effect of urban sprawl is very positive and significant in the municipalities of more than 5,000 inhabitants, with an increase of spending of $23 \%$.

- In the spending on Waste collection, elimination, and treatment (E162), the effect differs according to the town's size. There is a significant and very positive effect in 
municipalities with more than 5,000 inhabitants which means a $48 \%$ increase in spending. The effect is lower although significant in municipalities with 1,000 to 5,000 inhabitants (an increase of 20\%) while it is not significant in municipalities with fewer than 1,000 inhabitants.

- In expenditure on Road cleaning (E163), the effect is positive and significant only in municipalities with more than 5,000 inhabitants.

- In expenditure on Public lighting (E165), a significant positive effect was only demonstrated in the case of municipalities with more than 5,000 inhabitants, with an increase of $17 \%$ in expenditure on public lighting.

In the expenditure variable in Environment (E17), the effect of urban sprawl was significantly positive even when it was with a worse estimate and without relevant differences in town size. In the expenditure subvariable in Parks and Gardens (E171) there is a positive and significant effect in the case of municipalities with more than 1,000 inhabitants. This result coincides with the conclusions in Carruthers et al. (2003) who attributes higher spending on parks to the need for more parks to provide equal access to the facilities.

\section{Conclusions}

The regression formula model reveals a significant effect of urban sprawl on current expenditure of municipalities, especially in municipalities with more than 5,000 inhabitants.

The effect does not transfer in a homogeneous way to all of the municipal budget. Urban sprawl generates very different effects according to the expenditure variables. This shows how certain expenditure variables in municipal budgets are more sensitive to urban sprawl. The location or distribution of the population in the territory plays a major role in the expenditure variables associated with providing basic public services. Its effect is greatest on security and public transportation and community wellbeing, which primarily covers waste collection, elimination, and treatment; sanitation, and water supply and distribution; road cleaning; and public lighting.

The effects calculated in the expenditure are not linear and depend on the town's size. Independently of the quality of the data added to the model, it reveals significant effects according to the town's size in a same expenditure variable. This is consistent with the obligations and powers of the Town Councils which vary depending on the size of the municipality, and with previous studies on the importance of the size of the town and of the economies of scale in the local administration's expenditure (Solé-Ollé, 2001; Hortas-Rico, 2014).

In relation to other studies, where the characterization of the urban space is partial and mainly uses density (Solé-Ollé, 2001; Carruthers et al., 2003; Solé-Ollé et al., 2008; Hortas-Rico, 2010; Benito et al., 2010; Hortas-Rico et al., 2013), this methodology suggests a more complete characterization of the urban sprawl phenomenon. The model proposed and the effects calculated will be able to generate cost functions to build a model able to assess the increase in municipal expenditure in the different spending variables based on the projected urban development model. This model will constitute a valuable tool for urban planning decisionmaking and assessment of the economic sustainability of new urban growth. 


\section{References}

Benito, B.; Bastida, F.; Guillamón, M.D. (2010): Urban Sprawl and the Cost of Public Services: An Evaluation of Spanish Local Governments, Lex Localis - Journal of local self-government, 8(3). 2010, pp. 245-264. DOI 10.4335/8.3.245-264(2010).

Brooks, S.; Gelman, A.; Jones, G.; Meng, X.L. (2011): Handbook of Markov Chain Monte Carlo. CRC press, 2011. $619 \mathrm{p}$.

Brueckner, J. (2001): Urban Sprawl: Lessons from Urban Economics, in Brookings-Wharton Papers on Urban Affairs. William G. Gale and Janet Rothenberg Pack, eds. Washington, D.C.: Brookings Institution Press, pp. 65-89.

Burchell, R.W.; Mukherji, S. (2003): Conventional Development Versus Managed Growth: The Costs of Sprawl. American Journal of Public Health, 2003, 93(9), pp. 1534-1540.

Burriel, E. L. (2008): La "década prodigiosa” del urbanismo español (1997-2006). Scripta Nova. Revista Electrónica de Geografía y Ciencias Sociales. Barcelona, 2008, vol. XII, núm. 270 (64).

Cabasés, F.; Ezcurr, R.; Pascual, P. (2012): Usos del suelo urbano y situación financiera municipal. XIX Encuentro de Economía Pública: Políticas Públicas para la salida de la crisis, 2012, 41p.

Carruthers, J; Ulfarsson, G. (2003); Urban sprawl and the cost of public services. Environment and Planning B: Planning and Design, 2008, 30(4), pp. $503-522$.

European Environmental Agency (EEA) (2006): Urban sprawl in Europe. The ignored challenge. EEA. Report № 10/2006.

Ewing, R. (2008): Characteristics, causes, and effects of sprawl: a literature review. Urban Ecology, vol. 21. CollegePark, Maryland, USA: Springer, pp. 519-535.

Fortbou, J. (2005) Informe del sobre las alegaciones de aplicación abusiva de la LRAU y sus repercusiones para los ciudadanos europeos, Parlamento Europeo, 382/2005, Comisión de Peticiones.

Gaja i Díaz, F. (2008): El "tsunami urbanizador" en el litoral mediterráneo. El ciclo de hiperproducción inmobiliaria 1996-2006. Scripta Nova. Revista Electrónica de Geografía y Ciencias Sociales. Barcelona: Universidad de Barcelona, 2008, vol. XII, núm. 270 (66).

Garbiñe, H. (2007): Los costes económicos y sociales de la ciudad de baja densidad. En Indovina, F. (Coord.) La ciudad de baja densidad, lógicas y contención. Diputación Provincial de Barcelona, pp. 203-240.

Garrido, F.J.; Magrinyà, F.; Del Moral, M.C. (2013): Relación entre variables de ordenación urbanística y coste de explotación de los servicios públicos urbanos: evolución histórica. ACE: Architecture, City and Environment = Arquitectura, Ciudad y Entorno, 8 (23): 11-32, 2013. DOI: 10.5821/ace.8.23.2595

Gelman, A.; Rubin, D. (1992): Inference from iterative simulation using multiple sequences. Stat. Sci., 7, pp. 457-472.

Geman, S.; Geman, D. (1984): Stochastic relaxation, gibbs distributions, and the bayesian restoration of images. IEEE Trans Pattern Anal Mach Intell. 1984, 6(6), pp. 721-41. 
Gielen, E.; Riutort-Mayol, G.; Palencia Jiménez, J.S.; Cantarino-Martí, I. (2018). An urban sprawl index based on multivariate and Bayesian factor analysis with application at the municipality level in Valencia. Environment and Planning B-Planning \& Design, 45(5), pp. 888-914. DOI: $10.1177 / 2399808317690148$

Hortas-Rico, M.; Solé-Ollé, A. (2010): Does Urban Sprawl Increase the Costs of Providing Local Public Services? Evidence from Spanish Municipalities. Urban Studies, 2010, 47(7), pp. 15131540.

Hortas-Rico, M. (2014): Urban sprawl and municipal budgets in Spain: a dynamic panel data analysis, Papers in Regional Science, 93 (4), pp. 843-864.

Lunn, D.J.; Thomas, A.; Best, N.; Spiegelhalter, D. (2000): Winbugs - a Bayesian modelling framework: concepts, structure, and extensibility, Statistics and computing, 2000, 10(4), pp. 325-337.

Miralles, J.L.; García-Ayllon, S. (2013): The economic sustainability in urban planning: the case of La Manga. WIT Transactions on Ecology and the Environment, 2013, 173, pp 279-290. doi:10.2495/SDP130231

Miralles, J.L. (2014): El darrer cicle immobiliari al País Valencià. O el progrés de la misèria. Fundació Nexe, 2014. Demos, 5. 108 p.

Moral, C.; Garrido, F. (2010): Influencia de la edificabilidad y la densidad en los análisis ingresosgastos de los nuevos crecimientos urbanos. International Conference Virtual City and Territory. "6to. Congreso Internacional Ciudad y Territorio Virtual, Mexicali, 5, 6 y 7 Octubre 2010". Mexicali: UABC, 2010.

Muñiz, I.; García, M.A.; Calatayud, D. (2006): SPRAWL. Definición, causas y efectos. Volumen 6 de Document de treball / Universitat Autònoma de Barcelona. Departament d'Economia Aplicada, 2006, 39 p.

Ntzoufras, I. (2009): Bayesian Modeling using WinBUGS. Wiley, 2009, 520 p.

Office Féderal du Developpement Territorial (2000): Les coûts des infrastructures augmentent avec la dispersion des constructions (Dossier 4.00). Berna, Office Féderal du Developpement Territorial, 2

Paradinas, I.; Conesa, D.; Pennino, M. G.; Munoz, F.; Fernandez, A. M.; Lopez-Quilez, A.; Maria Bellido, J. (2015): Bayesian spatio-temporal approach to identifying fish nurseries by validating persistence areas. Marine Ecology Progress Series, 2015, 528, pp. 245-255.

Paulsen, K. (2013): The Effects of Land Development on Municipal Finance. Journal of Planning Literature. 2013; 29(1), pp. 20-40. doi:10.1177/0885412213497982

Pichler, N. (2007): European Urban Sprawl: Sustainability, Cultures of (Anti)Urbanism and "Hybrid Cityscapes". Dela 27, 2007, pp. 101-133.

RERC. Real Estate Research Corporation. (1974): The Cost of Sprawl, Environment and Economic Costs of Alternative Residential Development Patterns at the Urban Fringe. Washington D.C., U.S. Government Printing Office, 1974. 278 p.

Sapena, M.; Ruiz, L.A. (2015): Description and extraction of urban fragmentation indices: The Indifrag tool. Revista de Teledetección, 2015, 43, pp. 77-90. doi.org/10.4995/raet.2015.3476. 
Solé-Ollé, A. (2001): Determinantes del gasto público local: ¿necesidades de gasto o capacidad fiscal? En: Revista de economía aplicada. 2001, 9 (25), pp. 115-156.

Solé-Ollé, A.; Bosch, N. (2005): On de relationship between local authority size and the costs of providing local services: Lessons for the design of intergovernmental transfers in Spain. Public Finance Review. 2005, 33 (3), pp. 343-384.

Solé-Ollé, A.; Hortas-Rico M. (2008): Does urban sprawl increase the costs of providing local public services? Evidence from Spanish municipalities. Documents de treball IEB, №. 6, 2008.

Speir, C.; Stephenson, K. (2002): Does Sprawl Cost Us All?. Journal of the American Planning Association. 2002, 68 (1), pp. 56-70. 


\section{Graphical representation of the effects of the sprawl index}

The next figures offer additional graphical representation of the model $\beta$-parameter estimates which are already described in tables 4,5 and 6 of the main document. They demonstrate the effect of the sprawl variable on the different expenditure variables, differentiated by type of population. The bar shows the average effect (with a 95\% credible interval). It visualizes the average of the effect of the sprawl variable on the expenditure variable and determines, according to its position with respect to a void effect, the direction (positive or negative) and the magnitude of the effect (the further from zero, the greater the effect). The bar's length shows the credible interval.

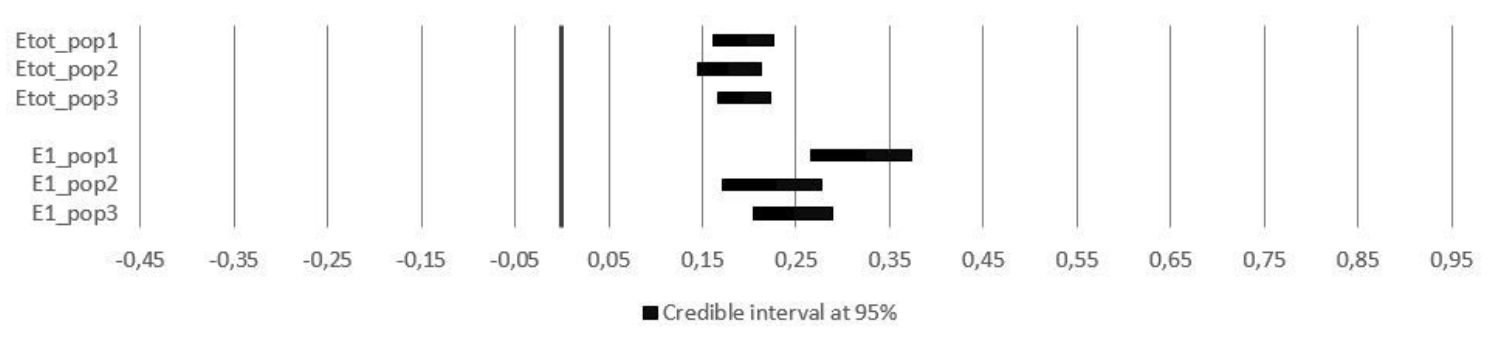

Figure: Effect of sprawl in Etot and E1

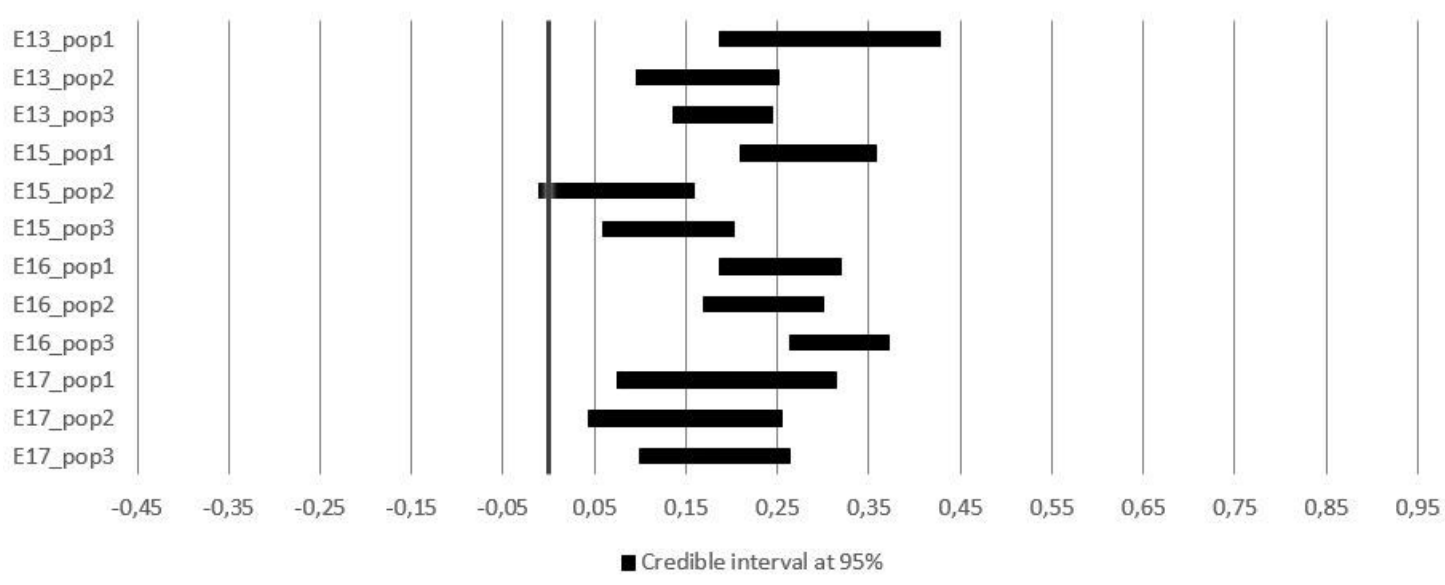

Figure: Effect of sprawl in E13, E15, E16 and E17 


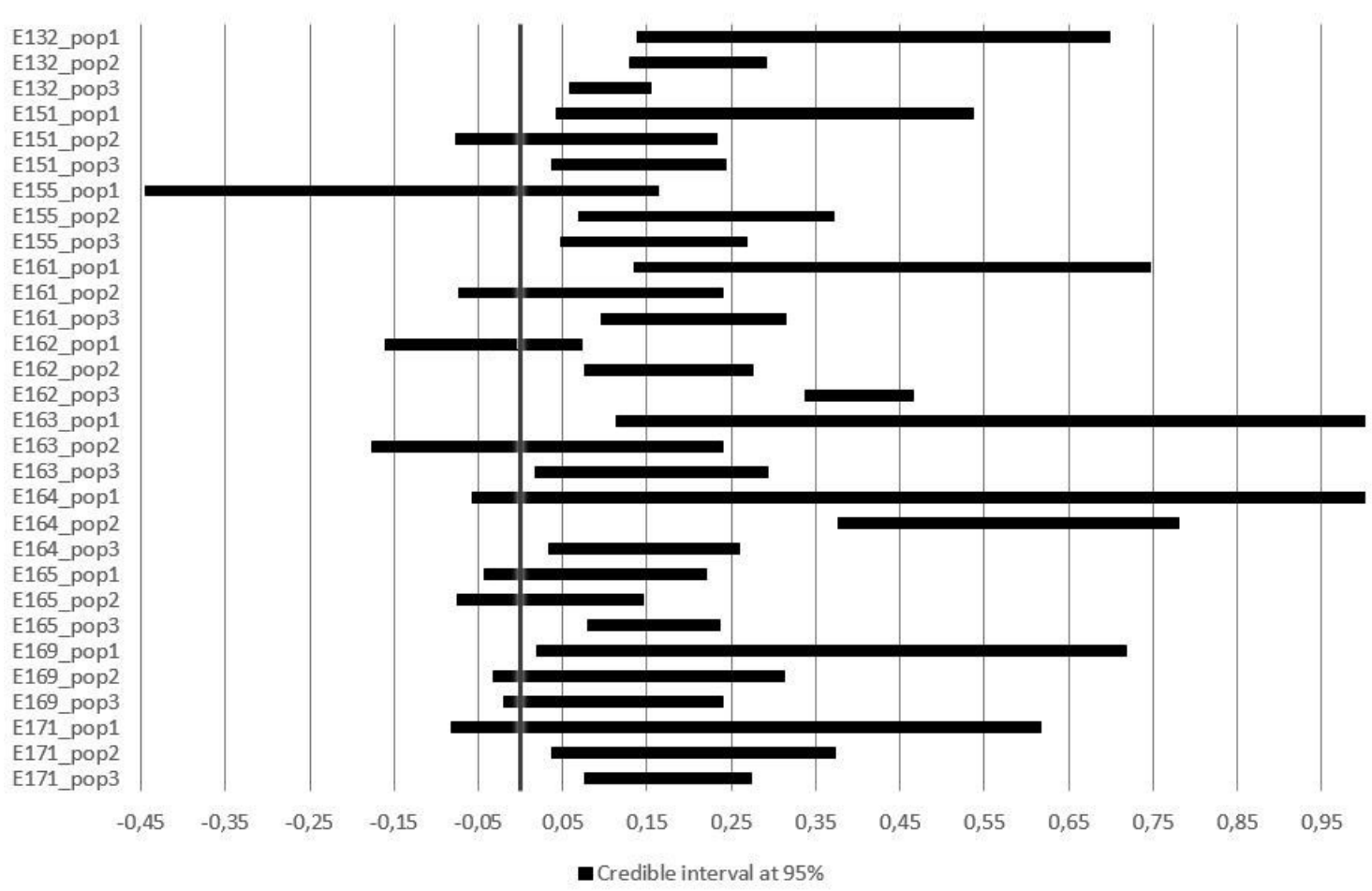

Figure: Effect of sprawl in variables of level 4 


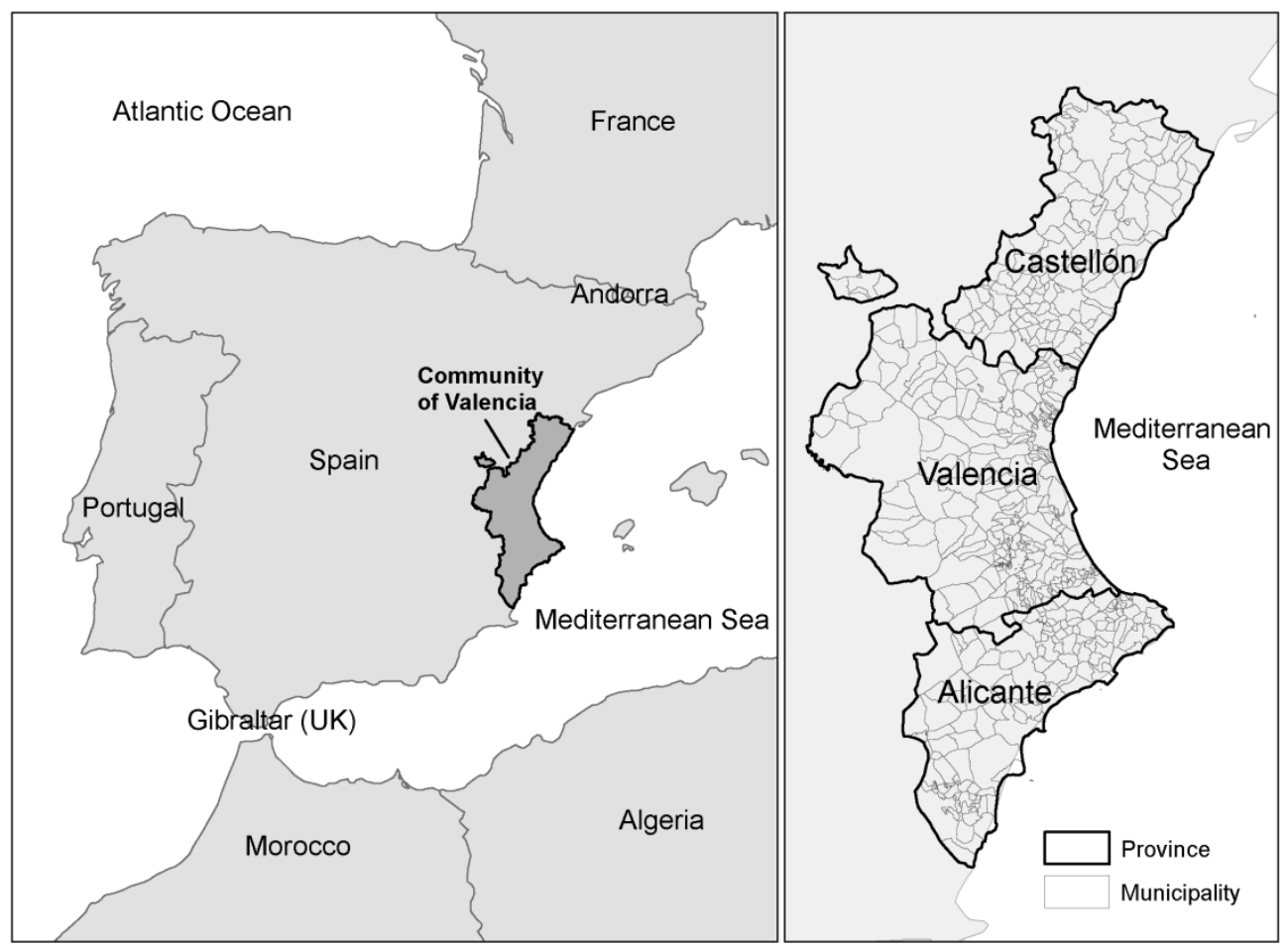

Figure 1: Area of study

$197 \times 147 \mathrm{~mm}(300 \times 300 \mathrm{DPI})$ 


\section{Model validation}

With the aim to check possible collinearity issues between the continuous explanatory variables including the sprawl index, a pre-analysis using Principal Components Analysis was conducted and non-significant correlations were recognized. On the other hand, it is known that there might be some correlation between the sprawl index and the population categories, which were handled in the modeling by including the interaction effects between those variables.

The convergence of the simulation chains based on MCMC was evaluated by the effective sample size of the chains statistic (Gelman et al., 1992), which was not over 1.05 for any one of the parameters.

The next figure shows the histograms of the residuals for the adjustment of all the response variables. Residuals seem random and normal distributed around zero showing a good fit-todata scenario.
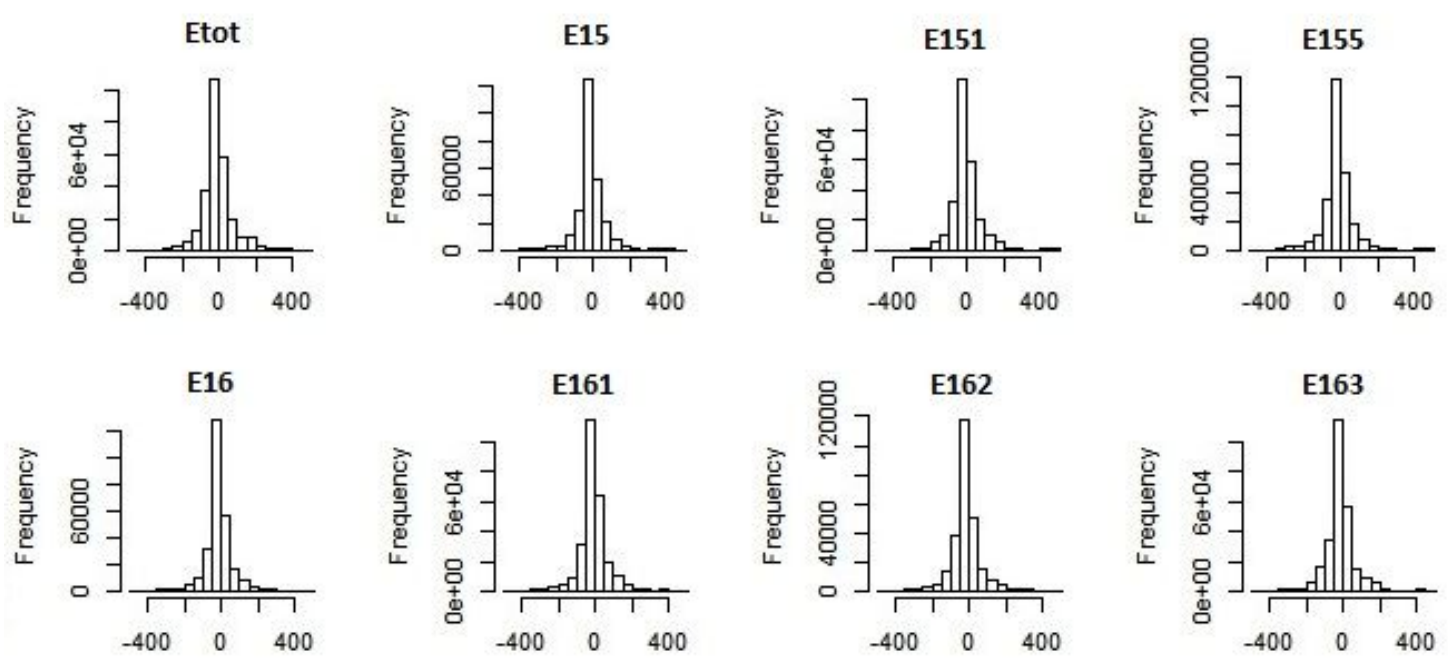

Figure: Histograms of the residuals of expenditure variables 